\title{
Kidney Cancer Pathologic Distant Metastasis TNM Finding v8
}

National Cancer Institute

\section{Source}

National Cancer Institute. Kidney Cancer Pathologic Distant Metastasis TNM Finding v8. NCI Thesaurus. Code C140280.

A pathologic finding about one or more characteristics of kidney cancer, following the rules of the TNM AJCC V8 classification system as they pertain to distant metastases. 